\title{
Tissue Protein Extraction
}

National Cancer Institute

\section{Source}

National Cancer Institute. Tissue Protein Extraction. NCI Thesaurus. Code C112985.

The isolation of proteins or protein solutions from a biological source material. 